\title{
Bacterial Reduction of Ferric Iron in a Stratified Eutrophic Lake
}

\author{
By J. GWYNFRYN JONES, ${ }^{*}$ STEVEN GARDENER AND \\ BERNARD M. SIMON \\ The Freshwater Biological Association, Windermere Laboratory, The Ferry House, Ambleside, \\ Cumbria LA22 OLP, U.K.
}

(Received 17 March 1982; revised 20 July 1982)

\begin{abstract}
The rate of release of $\mathrm{Fe}(\mathrm{II})$ from anoxic lake sediments was lower in the presence than in the absence of nitrate. The reduction of $\mathrm{Fe}$ (III) by the sediments had a temperature optimum of $30^{\circ} \mathrm{C}$ and was inhibited by $\mathrm{HgCl}_{2}$, suggesting that the process was largely biological in nature. Of the iron sources tested with cultures of anaerobic iron-reducing bacteria, $\mathrm{FeCl}_{3}$ was the most readily reduced and goethite the least. Reduction was faster in the presence of a chelating agent and was suppressed by the addition of $\mathrm{NO}_{3}^{-}, \mathrm{ClO}_{3}^{-}, \mathrm{MnO}_{2}, \mathrm{Mn}_{2} \mathrm{O}_{3}$ and $\mathrm{O}_{2}$. An iron-reducing chemoorganotroph, tentatively identified as a member of the genus Vibrio, was isolated. Physical contact between the bacterium and iron particles was essential to ensure maximum rates of $\mathrm{Fe}$ (III) reduction but $>30 \%$ of the activity appeared to be associated with extracellular components. Although Fe(III) reduction by whole cells and cell-free extracts was decreased in the presence of electron transport inhibitors, the molar growth yield of the organism was unaffected by the presence of Fe(III). It is assumed that the organism used the Fe(III) as a hydrogen sink. A second organism, an anaerobic facultative chemolithotroph, appeared to conserve energy by the reduction of Fe(III). Biomass yield (measured as ATP) was greater in the presence of $\mathrm{Fe}(\mathrm{III})$, and the organism was able to use $\mathrm{H}_{2}$ as a source of reducing power.
\end{abstract}

\section{INTRODUCTION}

Much of the ecological work on iron reduction has been concerned with bacterial activity in waterlogged soils. Of the genera isolated which were able to reduce $\mathrm{Fe}$ (III) (Ottow \& Glathe, 1971), many were facultative anaerobes and possessed dissimilatory nitrate reductases. These enzymes were implicated in the process (Ottow \& Munch, 1978) particularly since nitrate reductaseless mutants were unable to reduce $\mathrm{Fe}(\mathrm{III})$ (Ottow, 1970). The reduction of $\mathrm{Fe}$ (III) by organisms possessing nitrate reductase was suppressed by the addition of $\mathrm{NO}_{3}^{-}$or $\mathrm{MnO}_{2}$, whereas those which did not possess the enzyme were inhibited only by $\mathrm{MnO}_{2}$. Munch \& Ottow (1977) suggested that a specific ferrireductase was responsible for reduction in the latter. Lascelles \& Burkes (1978) concluded that Fe(III) was reduced by Staphylococcus aureus by electron transport chain components which preceded cytochrome $b$, but which were preferentially oxidized by a nitrate reductase system. On the other hand it has been proposed that the apparent effect of $\mathrm{NO}_{3}^{-}$in $\mathrm{Fe}$ (III) reduction may be due, under certain circumstances, to reoxidation of the $\mathrm{Fe}$ (II) by the $\mathrm{NO}_{2}^{-}$formed (Obueke et al., 1981). Munch \& Ottow (1982) demonstrated that physical contact was necessary for bacterial electron transport to ferric iron, yet extracellular reduction of $\mathrm{Fe}$ (III) took place in aerobic cultures of a marine diatom (Anderson \& Morel, 1980).

Electron transport phosphorylation coupled to $\mathrm{Fe}(\mathrm{III})$ reduction is thermodynamically feasible given the redox potential of the $\mathrm{Fe}^{3+} / \mathrm{Fe}^{2+}$ couple, and a $\Delta \mathrm{G}^{0 \prime}$ of $-228 \cdot 3 \mathrm{~kJ} \mathrm{~mol}^{-1}$ for the reaction $2 \mathrm{Fe}^{3+}+\left[\mathrm{H}_{2}\right] \rightarrow 2 \mathrm{Fe}^{2+}+2 \mathrm{H}^{+}$(Thauer et al., 1977) yet few attempts have been

Abbreviations: CCCP, carbonyl cyanide m-chlorophenylhydrazone; DNP, 2,4-dinitrophenol; HOQNO, 2-heptyl-4-hydroxyquinoline- $N$-oxide; TPTZ, 2,4,6-tripyridyl-1,3,5-triazine. 
made to determine whether bacteria obtain energy from the process. Takai \& Kamura (1966) reported that bacteria isolated from a waterlogged paddy soil grew five times faster in the presence of $\mathrm{Fe}(\mathrm{OH})_{3}$ than in its absence, and that growth was proportional to the amount of Fe(II) produced. They did not, however, include any results which supported these statements. Balashova \& Zavarzin (1979) isolated a pseudomonad which was both a facultative anaerobe and a facultative chemolithotroph. This organism reduced $\mathrm{Fe}$ (III) with $\mathrm{H}_{2}$ as the electron donor, and plate counts were $10^{3}$ times higher after $10 \mathrm{~d}$ incubation in the presence of $\mathrm{Fe}$ (III) than in its absence. In a study with cell-free extracts, Lascelles \& Burke (1978) showed that the inhibitors HOQNO and azide did not directly affect the reduction of Fe(III) by membrane fractions.

The reduction of Fe(III) occurs in eutrophic lakes (Mortimer, 1941, 1942) and the dynamics of the process have been studied in some detail (Davison et al., 1981; Verdouw \& Dekkers, 1980). The upward transport of $\mathrm{Fe}$ (II) by turbulence and its oxidation to hydrous ferric oxide on contact with oxygenated water produces a distinctive turbidity profile in the hypolimnion. The shape and movement of the turbidity peak provides valuable information on the balance between turbulence and reducing conditions (Davison et al., 1981) as well as the location of certain bacterial populations (Jones, 1981). The mechanism of Fe(III) reduction, however, requires investigation and this paper examines the distribution and physiology of iron-reducing bacteria in a stratified eutrophic lake.

\section{METHODS}

Sampling site and procedure. Samples were taken from Blelham Tarn (English Lake District: $54^{\circ} 24^{\prime} \mathrm{N}, 2^{\circ} 59^{\prime} \mathrm{W}$ ) and all field procedures were as described by Jones et al. (1982) and Jones (1981).

Core tube experiments. Sediment cores were taken from the profundal zone of Blelham Tarn before the onset of summer stratification. The water above the sediment was analysed for major ions, particularly potential electron acceptors. The water was then removed and replaced, with minimum disturbance of the sediment, by a chemically defined salts solution based on the above analysis. This contained $\left(\mu \mathrm{mol} 1^{-1}\right.$ in distilled $\left.\mathrm{H}_{2} \mathrm{O}\right): \mathrm{NaHCO}_{3}, 320$; $\mathrm{K}_{2} \mathrm{HPO}_{4}, 0.25 ; \mathrm{CaCl}_{2}, 250 ; \mathrm{MgSO}_{4}, 110 ;\left(\mathrm{NH}_{4}\right)_{2} \mathrm{SO}_{4}, 10 ; \mathrm{KNO}_{3}, 70$. A second solution, in which the $\mathrm{KNO}_{3}$ was replaced by $70 \mu \mathrm{mol} \mathrm{KC1} 1^{-1}$, was also prepared to determine the effect of $\mathrm{NO}_{3}^{-}$on $\mathrm{Fe}$ (III) reduction. Unstoppered sediment cores were incubated for $16 \mathrm{~h}$ at $8{ }^{\circ} \mathrm{C}$ and the overlying water was replaced once again by the chemically defined solutions. It was hoped that this treatment would establish relatively reproducible gradients of electron acceptors within the sediment while allowing the experiment to start with overlying water of known composition. The tubes were then stoppered after inserting magnetic stirring vanes (Jones, 1976). The upper stopper contained two wide-gauge syringe needles, one for removal of water samples and the other attached to a reservoir of the minerals solution which had been degassed and maintained under a slight pressure of $\mathbf{N}_{2}$. The cores were incubated at $20^{\circ} \mathrm{C}$ and the water stirred gently immediately before removal of small $(\leqslant 1 \%$ of the volume of overlying water) samples for chemical analysis.

Chemical analysis. Nitrate and $\mathrm{Mn}(\mathrm{II})$ were determined according to Mackereth et al. (1978) and $\mathrm{Fe}(\mathrm{II})$ with TPTZ (Standing Committee of Analysts, 1977).

Enumeration of bacteria which reduced or deposited $F e(I I I)$. The semi-solid media and procedures used were as described by Jones (1983).

Isolation of Fe(III)-reducing bacteria. Primary enrichments in semi-solid agar media were subcultured on to plates of solid medium from which Fe(II) had been omitted. Immediately after visible growth of a colony was detected, a small portion of agar adjacent to it was removed and tested for the presence of Fe(II) with TPTZ. Colonies which showed the strongest reaction were subcultured into liquid medium. These cultures, designated mixed enrichment cultures at this stage, were transferred several times from liquid to solid media of the same composition as the medium used for isolation, and were periodically checked for purity on medium which also contained $100 \mathrm{mg} \mathrm{l}^{-1}$ each of peptone and yeast extract. Although they originated from single colonies, several passages through this process were necessary to ensure purity of the cultures, particularly those of the $\mathrm{H}_{2}$-utilizing anaerobes. The bacteria were treated as strict anaerobes and were cultured using a serum vial modification of the Hungate technique (Latham \& Wolin, 1978). The gas mixtures were purified by passage through commercially available oxygen traps which had previously been shown to reduce $\mathrm{O}_{2}$ levels sufficiently to allow growth of methanogens (Jones et al., 1982). Hydrogen utilization was detected as a drop in pressure and by gas chromatographic analysis of the head space.

Measurement of bacterial growth. The dry weight of pure cultures was determined and corrected for the quantity of $\mathrm{Fe}$ (III) present after three washings with distilled water. Before measuring the turbidity of liquid cultures $5 \mu \mathrm{l}$ of $10 \mathrm{~mol}^{-1} \mathrm{HCl}$ was added to $1 \mathrm{ml}$ of culture to dissolve completely the ferric oxy-hydroxides. The addition of acid did not affect the turbidity of cultures grown in the absence of $\mathrm{Fe}(\mathrm{III})$. Very good linearity was obtained between 
dry weight and turbidity determinations. ATP was determined by a sensitive modification of the luciferinluciferase procedure (Jones \& Simon, 1977). Samples were injected directly either into boiling Tris buffer pH 7.8, or into an equal volume of ice-cold $10 \%$ (w/v) TCA containing $4 \mathrm{mmol} \mathrm{EDTA}^{-1}$; the latter were diluted to 50 -fold in buffer before analysis. Direct counts of bacteria were made by epifluorescence microscopy (Jones \& Simon, 1975). When glucose was used as substrate its concentration in the growth medium was determined by conversion to gluconate 6-phosphate with stoichiometric production of NADPH (Boehringer Mannheim Test Kit, code no. 139106). Molar growth yields were determined both as the final dry weight obtained from a given concentration of glucose, and as the relationship between increase in turbidity and glucose utilization during the early exponential phase of growth.

Cell-free extracts. Cells were harvested anaerobically by centrifugation at $6000 \mathrm{~g}$ for $30 \mathrm{~min}$, and the pellet was resuspended and washed in $50 \mathrm{mmol}^{-1}$ Tris/ $\mathrm{HCl}$ buffer, $\mathrm{pH} 7 \cdot 2$. The cells were finally resuspended in $10 \mathrm{ml}$ of buffer, treated for $2 \mathrm{~min}$ in an ultrasonic disintegrator set to an amplitude of $12 \mu \mathrm{m}$, and then centrifuged at $10000 \mathrm{~g}$ for $30 \mathrm{~min}$. The supernatant was used as a crude cell-free extract either immediately or after storage on ice under $\mathrm{N}_{2}$. The protein content of the extract was determined by the Coomassie Brilliant Blue dye binding technique (Bradford, 1976). The reaction mixture (final $\mathrm{pH} \mathrm{6.8)} \mathrm{used} \mathrm{to} \mathrm{measure} \mathrm{Fe(III)} \mathrm{reduction} \mathrm{by} \mathrm{cell-free}$ extracts contained: enzyme preparation (100 vols); $\mathrm{MgCl}_{2}, 1 \mathrm{~mol} \mathrm{l}^{-1}, \mathrm{~K}_{2} \mathrm{HPO}_{4}, 1.2 \mathrm{~mol} \mathrm{l}^{-1}$ (1 vol); ADP, $200 \mathrm{mmol} \mathrm{l}^{-1}(1 \mathrm{vol})$; NADH, $300 \mathrm{mmol}^{-1}(1 \mathrm{vol}) ; \mathrm{FeCl}_{3}, 500 \mathrm{mmol}^{-1}(1 \mathrm{vol})$. The following inhibitors were added as $\times 100$ strength solutions; the final concentrations $\left(\mathrm{mol}^{-1}\right)$ were: rotenone, $10^{-5} ; \mathrm{HOQNO}^{-4} ; \mathrm{ClO}_{3}^{-}$, $5 \times 10^{-3}$; antimycin $\mathrm{A}, 10^{-4}$ [or $0 \cdot 15 \mu \mathrm{g}$ (mg protein $)^{-1}$ ]; $\mathrm{NaN}_{3}, 10^{-3}$ and $10^{-5} ; \mathrm{DNP}, 10^{-4} ; \mathrm{CCCP}, 10^{-6}$. These inhibitors were also used to treat growing cultures of $\mathrm{Fe}(\mathrm{III})$-reducing bacteria.

Effect of direct contact on bacterial iron reduction. Bacteria were grown in standard medium in $100 \mathrm{ml}$ serum vials. In control vials $\mathrm{FeCl}_{3}$ was incorporated in the medium to a final concentration of $0.4 \mathrm{mmol}^{-1}$. In the test vials the $\mathrm{FeCl}_{3}$ was contained in a dialysis bag (Visking tubing $6 \mathrm{~mm}$ diameter, $0.32 \mathrm{~mm}$ wall thickness and nominal mol. wt cut off about 10000). The amount of $\mathrm{FeCl}_{3}$ in the dialysis bag was equivalent to a final concentration of $0.4 \mathrm{mmol} \mathrm{l}^{-1}$ in the $50 \mathrm{ml}$ of medium in the vial. The $\mathrm{FeCl}_{3}$ was made up in complete medium, set to $\mathrm{pH} 6.8$ and allowed to flocculate overnight before the dialysis bags were introduced into vials. The possibility of extracellular reduction of $\mathrm{Fe}$ (III) was tested by removal of bacteria at the end of an experiment by centrifugation at $5000 \mathrm{~g}$ for $45 \mathrm{~min}$ at $4{ }^{\circ} \mathrm{C}$ followed by filtration of the supernatant through $0 \cdot 2 \mu \mathrm{m}$ pore size polycarbonate filters (Nuclepore). The cell-free medium was then incubated anaerobically with $\mathrm{FeCl}_{3}$ added to a final concentration of $0.4 \mathrm{mmol}^{-1}$. All manipulations were carried out in the anaerobic handling chamber.

\section{RESULTS}

\section{Iron reduction in sediments and by bacteria}

The reduction and reprecipitation of $\mathrm{Fe}(\mathrm{III})$ in a stratified eutrophic lake produces a characteristic turbidity profile. Such a profile, and most probable number counts of irondepositing and iron-reducing bacteria in the water column, are shown in Fig. 1. The population of reducers was the larger by almost an order of magnitude, averaging about 500 bacteria ml-1, $^{-1}$ but the difference may merely reflect the efficiency of recovery on the two media used. A more detailed examination of the water-borne population about the turbidity peak showed that counts of iron reducers at the peak were three to four times higher than those either side. The numbers were decreased by $60-90 \%$ if $\mathrm{NO}_{3}^{-}$was incorporated in the medium. Iron-depositing bacteria were more numerous $\left(3.9 \times 10^{4} \mathrm{ml}^{-1}\right)$ in the oxidized littoral sediment than in the anoxic profundal mud $\left(2.7 \times 10^{4} \mathrm{ml}^{-1}\right)$ whereas, as might be expected, the reverse was true of bacteria which reduced $\mathrm{Fe}$ (III) (counts of $1.3 \times 10^{4} \mathrm{ml}^{-1}$ and $8.2 \times 10^{4} \mathrm{ml}^{-1}$, respectively, in the two zones). The rate of release of $\mathrm{Fe}(\mathrm{II})$ from profundal sediments was measured in sealed sediment cores (Fig. 2). The Fe(II) concentration did not begin to rise appreciably until the oxygen was depleted $(70 \mathrm{~h})$, when a release rate of $2 \cdot 2 \mu \mathrm{mol} \mathrm{l}^{-1} \mathrm{~h}^{-1}$ was observed. The presence of $\mathrm{NO}_{3}^{-}$in the overlying water resulted in a slower release of $\mathrm{Fe}(\mathrm{II})$ until all the $\mathrm{NO}_{3}^{-}$had been respired anaerobically $(190 \mathrm{~h})$. The $\mathrm{NO}_{3}^{-}$may have been involved in any of the three mechanisms mentioned in the Introduction, but its effect on the $E_{\mathrm{h}}$ and the chemical release of iron should not be discounted. The release of $\mathrm{Mn}$ (II) was relatively small and did not continue with time.

To determine the relative importance of the biological and chemical mechanisms for the reduction of $\mathrm{Fe}$ (III) we measured the effect of temperature and a biological poison on $\mathrm{Fe}(\mathrm{II})$ release from diluted profundal sediment. The presence of a clear temperature optimum (Fig. 3), and significant inhibition by $\mathrm{HgCl}_{2}$, suggested that the process was largely biological in nature. 
Dissolved $\mathrm{O}_{2}$
$(\mu \mathrm{mol} \mathrm{l}$
$-1)$
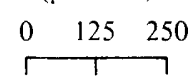

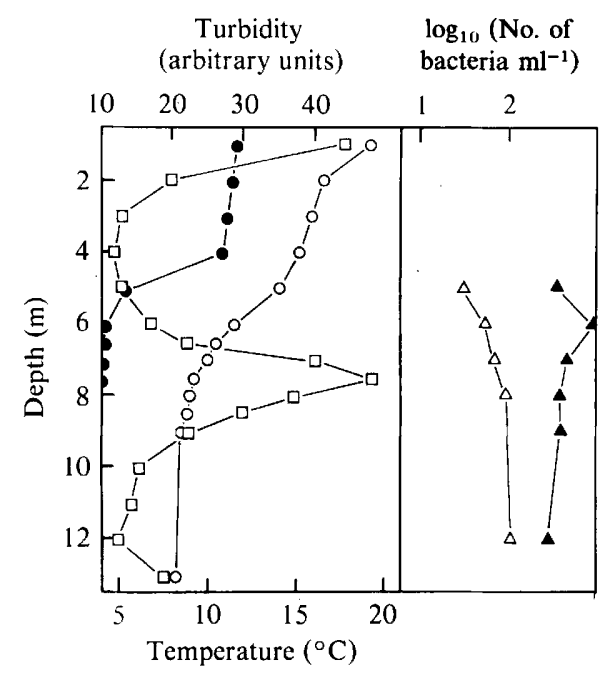

Fig. 1

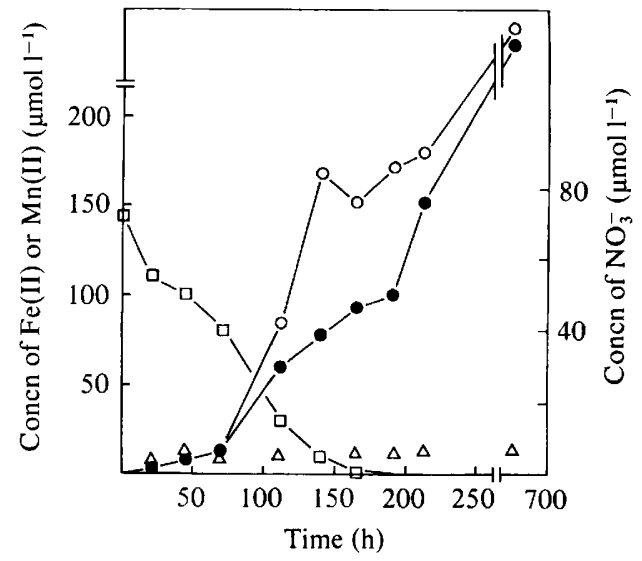

Fig. 2

Fig. 1. Distribution of temperature (O), dissolved oxygen (O), turbidity ( $\square$ ), numbers of Fe(III)depositing $(\triangle)$ and $\mathrm{Fe}(\mathrm{III})$-reducing $(\Delta)$ bacteria with depth in the water column of Blelham Tarn on 30 July 1981 . The $95 \%$ confidence limits of the log counts are $\pm 0 \cdot 30$.

Fig. 2. Release of $\mathrm{Fe}(\mathrm{II})$ from sediment in sealed cores in the presence $(\mathrm{O})$ and absence $(\mathrm{O})$ of $\mathrm{NO}_{3}^{-}$in the overlying water. Also shown is the removal of $\mathrm{NO}_{3}^{-}(\square)$ and the accumulation of $\mathrm{Mn}(\mathrm{II})(\triangle)$. The cores were taken from Blelham Tarn before the onset of summer stratification and incubated at $20^{\circ} \mathrm{C}$.

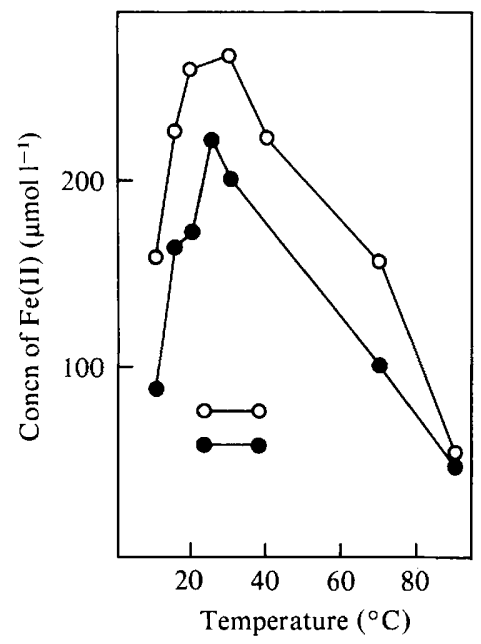

Fig. 3. Effect of temperature on the release of Fe(II) from profundal sediments of Blelham Tarn. Samples were incubated in serum bottles for $23 \mathrm{~h}(\mathrm{O})$ and $96 \mathrm{~h}(\mathrm{O})$ under an atmosphere of $95 \% \mathrm{~N}_{2} / 5 \%$ $\mathrm{CO}_{2}$. The horizontal lines indicate $\mathrm{Fe}(\mathrm{II})$ release at $30^{\circ} \mathrm{C}$ over the same time periods after treatment with $\mathrm{HgCl}_{2}$ at a final concentration of $100 \mathrm{mg} \mathrm{l}^{-1}$. 
Table 1. Effect of electron acceptor and electron donor on $\mathrm{Fe}(\mathrm{III})$ reduction in mixed enrichment cultures of sediment bacteria

\begin{tabular}{|c|c|c|c|c|}
\hline \multirow{3}{*}{$\begin{array}{r}\text { Gas phase } \ldots \\
\text { Organic } \mathrm{C} \text { and } \mathrm{N} \dagger \ldots\end{array}$} & \multicolumn{4}{|c|}{ Rate of $\mathrm{Fe}(\mathrm{II})$ formation* } \\
\hline & \multicolumn{2}{|c|}{$80 \% \mathrm{H}_{2} / 20 \% \mathrm{CO}_{2}$} & \multicolumn{2}{|c|}{$95 \% \mathrm{~N}_{2} / 5 \% \mathrm{CO}_{2}$} \\
\hline & Present & Absent & Present & Absent \\
\hline $\begin{array}{l}\mathrm{FeCl}_{3} \\
\mathrm{FePO}_{4} \\
\mathrm{Fe}_{2} \mathrm{O}_{3} \\
\text { Goethite }\end{array}$ & $\begin{array}{r}100 \\
76 \\
58 \\
40\end{array}$ & $\begin{array}{l}4 \cdot 5 \\
1 \cdot 3 \\
1 \cdot 1 \\
1 \cdot 1\end{array}$ & $\begin{array}{l}83 \\
68 \\
41 \\
21\end{array}$ & $\begin{array}{l}0 \cdot 3 \\
0 \cdot 2 \\
\text { ND } \\
\text { ND }\end{array}$ \\
\hline
\end{tabular}

ND, Not detectable.

* Expressed as a percentage of that obtained with $\mathrm{FeCl}_{3}$ in the presence of organic $\mathrm{C}$ and $\mathrm{N}$ and under a $\mathrm{H}_{2} / \mathrm{CO}_{2}$ atmosphere.

$\dagger$ Added as glucose $100 \mathrm{mg}^{-1}$, peptone $100 \mathrm{mg}^{-1}$, yeast extract $10 \mathrm{mg} \mathrm{l}^{-1}$.

$\ddagger$ At $0.4 \mathrm{mmol}^{-1}$.

The residual activity after addition of $\mathrm{HgCl}_{2}$ at $30^{\circ} \mathrm{C}$ was of the same order as that observed in control samples at $90^{\circ} \mathrm{C}$, indicating that both methods provided similar estimates of the chemical component.

The profundal sediment was a major sink for iron, with a concentration of about 50$60 \mathrm{mg} \mathrm{g}^{-1}$ (approximately equivalent to $2 \cdot 5-3.0 \mathrm{~g} \mathrm{l}^{-1}$ of wet sediment) in the top $1 \mathrm{~cm}$, and therefore we chose to examine the population of $\mathrm{Fe}$ (III)-reducing bacteria in the sediment, where the larger quantities of the potential electron acceptor were found. Although these cultures were obtained from single colonies they were designated as mixed enrichments (see Methods) until they had been subjected to several passages through a variety of liquid and solid media. This was particularly important in the case of the $\mathrm{H}_{2}$-utilizing anaerobes, which were difficult to separate from associated chemoorganotrophs. All the sources of Fe(III) provided were reduced by the bacteria (Table 1), the rates being much faster $\left(30-100 \mu \mathrm{mol} \mathrm{l}^{-1} \mathrm{~d}^{-1}\right)$ in the presence of organic $\mathrm{C}$ and $\mathrm{N}$. The effect of the iron source was the same on both the chemoorganotrophic and chemolithotrophic enrichments, in that $\mathrm{FeCl}_{3}$ provided the most readily reduced form of iron and goethite the least. The $\mathrm{FeCl}_{3}$ will hydrolyse immediately on addition to the liquid medium, and will then flocculate over a longer time period, the rate being governed, to some degree, by the ionic strength of the medium. To provide the $\mathrm{Fe}$ (III) in a more readily available, i.e. soluble, form, it is necessary to incorporate a chelating agent. Addition of citrate to the medium stimulated reduction by $70-220 \%$ depending on the organism involved, but we chose to omit chelating agents in experiments where growth on defined carbon sources was required. The mixed enrichments were finally tested for their response to alternative electron acceptors in the presence of equimolar concentrations of $\mathrm{Fe}$ (III). The reduction of $\mathrm{Fe}(\mathrm{III})$ was suppressed by $\mathrm{NO}_{3}^{-}(35-95 \%), \mathrm{ClO}_{3}^{-}(45 \%), \mathrm{MnO}_{2}(64-93 \%), \mathrm{Mn}_{2} \mathrm{O}_{3}(75 \%)$ and $\mathrm{O}_{2}(>99 \%)$.

\section{Iron reduction by chemoorganotrophic bacteria}

Enrichment cultures in which glucose was the source of carbon and reducing power yielded a pure culture of a Gram-negative facultative anaerobe which activily reduced $\mathrm{Fe}$ (III). The bacterium was fermentative in Hugh \& Leifson medium, a rod 0.8-1.0 $\mu \mathrm{m}$ wide and $1.5-2.0 \mu \mathrm{m}$ long, and it possessed a single polar flagellum. It was catalase and oxidase positive, and sensitive to $\mathrm{O} / 129$. It was therefore tentatively assigned to the genus Vibrio. The optimum temperature for $\mathrm{Fe}$ (III) reduction was $30^{\circ} \mathrm{C}$ and the rate of reduction was dependent on $\mathrm{Fe}$ (III) concentration. Below $100 \mu \mathrm{mol} F e(\mathrm{III}) \mathrm{1}^{-1}$ the response to concentration was curvilinear, but above this inflexion activity increased in a linear manner from 25 to $140 \mu \mathrm{mol}^{-1} \mathrm{~d}^{-1} \mathrm{Fe}$ (II) produced at $1000 \mu \mathrm{mol} \mathrm{Fe}$ (III) $1^{-1}$, which was the highest concentration tested. This was interpreted in terms of a form of saturation kinetics at the lower concentration, with the linear response being attributed to increased frequency of contact between bacteria and the larger number of $\mathrm{Fe}_{2} \mathrm{O}_{3}$ particles at the higher concentrations. The need for direct contact was tested by separating the 


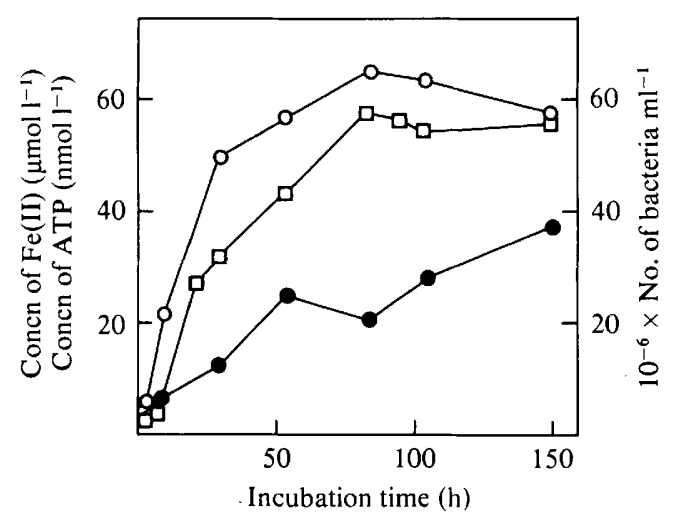

Fig. 4. Growth, as measured by ATP biomass (O) and direct counts $(O)$, and $F e(I I I)$ reduction ( $\square$ ) by a freshwater Vibrio sp. The organisms were grown in serum vials in a shaking water bath at $20^{\circ} \mathrm{C}$, with glucose $\left(5 \mathrm{mmol}^{-1}\right)$ as sole $\mathrm{C}$ and energy source. The gas phase was $95 \% \mathrm{~N}_{2} / 5 \% \mathrm{CO}_{2}$.

bacteria and the source of $\mathrm{Fe}$ (III) with a dialysis membrane. The rate of $\mathrm{Fe}$ (II) production $\left(\mu \mathrm{mol}{ }^{-1} \mathrm{~h}^{-1}, \pm 95 \%\right.$ confidence limits) decreased from $5.9 \pm 0.8$ to $1.04 \pm 0.29$, but this does not provide conclusive proof of a need for physical contact, since the membrane may also prevent passage of extracellular components responsible for reduction, as well as being permeable to small quantities of $\mathrm{FeCl}_{3}$ before hydrolysis/flocculation occurred. In an experiment in which the culture reduced $\mathrm{Fe}(\mathrm{III})$ at a rate of $6.1 \pm 0.96 \mu \mathrm{mol}^{-1} \mathrm{~h}^{-1}$, centrifuged and filtered spent medium reduced $\mathrm{Fe}(\mathrm{III})$ at $2.2 \pm 0.8 \mu \mathrm{mol} \mathrm{l}^{-1} \mathrm{~h}^{-1}$. This showed that extracellular components could account for $>30 \%$ of the reduction observed in a whole cell suspension.

Reduction of Fe(III) by the Vibrio sp. was closely correlated with growth, as measured by ATP biomass, and to a lesser degree with cell numbers (Fig. 4). There was good agreement between turbidity, protein content and dry weight of cells and a calibration curve was used to determine cell yield in future experiments. Growth was linear with glucose concentration up to $5 \mathrm{mmol}^{-1}$, at which point an inflexion in the growth curve was observed. The molar growth yield was unaffected by the presence of $\mathrm{Fe}$ (III) as was the final dry weight of the culture. In three separate experiments the molar growth yields in the presence of $\mathrm{Fe}$ (III) were $15.8,31.6$ and $24.3 \mathrm{~g}$ dry wt $\mathrm{mol}^{-1}$, and in its absence $14 \cdot 6,29 \cdot 2$ and $24 \cdot 3 \mathrm{~g} \mathrm{dry} \mathrm{wt} \mathrm{mol}^{-1}$, respectively. This suggested that the Vibrio sp. used $\mathrm{Fe}$ (III) as a hydrogen sink, i.e. to allow reoxidation of NADH rather than for energy conservation via electron transport phosphorylation. The effect of selected inhibitors was then tested on both whole cells and cell-free extracts of the bacterium. The reduction of $\mathrm{Fe}$ (III) by cell-free extracts was linear with time up to $6 \mathrm{~h}$, although a large chemical component (30-90\% of activity) was observed in control treatments during the first hour of incubation. Measurements were therefore made between 1 and $1.5 \mathrm{~h}$ incubation. The specific activity of extracts prepared under rigorously controlled anaerobic conditions $[1.6 \mu \mathrm{mol} F e($ III) reduced (mg protein) $)^{-1} \mathrm{~h}^{-1}$ ] was significantly higher than that of aerobic extracts $\left(0.07 \mu \mathrm{mol} \mathrm{mg}^{-1} \mathrm{~h}^{-1}\right)$ but the extraction yield was much less in the absence of $\mathrm{O}_{2}$. This presumably reflected the inefficiency of ultrasonic disruption under anaerobic conditions (Hughes et al., 1971). The range of activities obtained with aerobic extracts was $0.03-0.13 \mu \mathrm{mol} \mathrm{mg}^{-1} \mathrm{~h}^{-1}$. Inhibitors of electron transport, nitrate reductase, ATPase and ionophores all reduced the yield of $\mathrm{Fe}$ (II) in cell-free extracts although rotenone and antimycin A did not affect the activity of whole cells (Table 2). Negative results with whole cells are not, however, easily interpreted, since they may merely reflect inability to reach the site of activity within the cell. Although some inhibition of ATP production was observed in cell-free extracts, the analyses were unsatisfactory. This we attributed, in part, to interference of the chemiluminescent reaction by such large quantities of iron. Therefore, although we were able to demonstrate the involvement of an electron transport system in $\mathrm{Fe}$ (III) reduction there was no evidence of energy conservation, in terms of growth yield, from the whole cell experiments. 
Table 2. Inhibition of $\mathrm{Fe}(I I I)$ reduction in whole cells and cell-free extracts of a freshwater Vibrio sp.

\begin{tabular}{lcc} 
& \multicolumn{2}{c}{ Percentage inhibition* } \\
\cline { 2 - 3 } Inhibitor & Whole cells & Cell-free extracts \\
Rotenone & 0 & $61-52$ \\
HOQNO & 89 & $50-100$ \\
Antimycin A & 0 & $74-100$ \\
ClO $_{3}^{-}$ & - & $58-60$ \\
$\mathrm{NaN}_{3}$ & 36 & $56-66$ \\
DNP & 70 & 16 \\
CCCP & 34 & $6-79$
\end{tabular}

- , Not determined.

* The effect on whole cells was measured over $24 \mathrm{~h}$ and on cell-free extracts over $0.5 \mathrm{~h}$. The control rates of Fe(III) reduction $\left[\mu \mathrm{mol}(\mathrm{mg} \text { protein })^{-1} \mathrm{~h}^{-1}\right]$ were: whole cells, 0.873 ; cell-free extracts, 0.105 .

Table 3. Reduction of Fe(III) by a two-membered consortium and a pure culture of $a$ $\mathrm{H}_{2}$ utilizing anaerobe

\begin{tabular}{|c|c|c|c|c|c|c|}
\hline \multirow{3}{*}{$\begin{array}{c}\text { Culture } \\
\text { conditions }\end{array}$} & \multicolumn{3}{|c|}{ Consortium } & \multicolumn{3}{|c|}{ Pure culture } \\
\hline & \multirow{2}{*}{$\begin{array}{c}\mathrm{Fe}(\mathrm{II}) \\
\text { produced } \\
\left(\mu \mathrm{mol} \mathrm{I}^{-1}\right)\end{array}$} & \multicolumn{2}{|c|}{ ATP yield $\left(\mathrm{nmol} \mathrm{1}^{-1}\right)$} & \multirow{2}{*}{$\begin{array}{c}\mathrm{Fe}(\mathrm{II}) \\
\text { produced } \\
\left(\mu \mathrm{mol} \mathrm{1^{-1 } )}\right.\end{array}$} & \multicolumn{2}{|c|}{ ATP yield $\left(\mathrm{nmol} \mathrm{1}^{-1}\right)$} \\
\hline & & $+\mathrm{Fe}(\mathrm{III})$ & $-\mathrm{Fe}(\mathrm{III})$ & & $+\mathrm{Fe}$ (III) & $-\mathrm{Fe}(\mathrm{III})$ \\
\hline $\mathrm{H}_{2}$ only & 28 & 0.04 & 0.05 & 14 & 0.05 & 0.05 \\
\hline $\mathrm{H}_{2}+$ acetate & 41 & 0.29 & 0.05 & 7 & 0.08 & 0.05 \\
\hline $\mathrm{H}_{2}+$ yeast extract & 60 & 1.26 & 0.47 & 38 & 0.16 & 0.08 \\
\hline $\mathrm{N}_{2}+$ acetate & 6 & 0.05 & - & 7 & 0.04 & - \\
\hline $\mathrm{N}_{2}+$ yeast extract & 40 & 0.84 & - & 27 & $0 \cdot 15$ & - \\
\hline
\end{tabular}

-, Not determined.

* The consortia were incubated for $14 \mathrm{~d}$ and pure cultures for $28 \mathrm{~d}$ at $30^{\circ} \mathrm{C}$.

Iron reduction by mixed and pure cultures of a chemolithotrophic bacterium

It was extremely difficult to obtain pure cultures of anaerobic, chemolithotrophic bacteria which reduced $\mathrm{Fe}$ (III). An enrichment culture in which $\mathrm{H}_{2}$ was the source of reducing power, and $\mathrm{CO}_{2}$ the source of $\mathrm{C}$, reduced $\mathrm{Fe}$ (III) (the only potential electron transport acceptor in the medium). After several sub-cultures through solid and liquid media two organisms remained, which, together, reduced Fe(III) more rapidly than did the iron-reducing member of the consortium when it was eventually obtained in pure culture. This organism was a small Gramnegative cocco-bacillus, 0.9 to $1.2 \mu \mathrm{m}$ long. It was a facultative anaerobe and a facultative autotroph. Growth was enhanced by the presence of yeast extract but has been so slow, or has not occurred on conventional media that further characterization has not been possible. A greater biomass yield (measured as ATP) of both mixed and pure cultures was obtained in the presence of $\mathrm{Fe}$ (III) than in its absence (Table 3) on media to which yeast extract or acetate had been added. In addition to the increased biomass yield in the presence of Fe(III), larger quantities of $\mathrm{Fe}$ (II) and ATP were produced if the gas phase was $\mathrm{H}_{2} / \mathrm{CO}_{2}$. This suggested that hydrogen could act as major, if not sole source of reducing power for the reaction.

\section{DISCUSSION}

The results obtained with sealed sediment cores showed that such systems could be used as crude models of hypolimnetic processes. The absence of significant release of $\mathrm{Mn}$ (II) supported the suggestion by Davison (1981) that the sediment is not a major source of supply of this metal to the hypolimnion. The process of Fe(III) reduction has been shown to be largely biological in nature, and the activity of bacterial isolates was affected by the presence of $\mathrm{NO}_{3}^{-}, \mathrm{ClO}_{3}^{-}$and higher manganese oxides. The results with $\mathrm{ClO}_{3}^{-}$as well as $\mathrm{NO}_{3}^{-}$imply a direct involvement of 
nitrate reductase in at least some of the organisms. In others, where $\mathrm{ClO}_{3}^{-}$sensitivity was less, the inhibitory effect of $\mathrm{NO}_{3}^{-}$could have been due to its capacity to divert electron flow (Lascelles \& Burke, 1978). The suppression by higher manganese oxides is comparable with a separate reductase system such as those reported in soil organisms (Munch \& Ottow, 1977). The higher rates of reduction obtained with $\mathrm{FeCl}_{3}$ may have been due to the smaller particle size of the hydrolysed product and may more closely resemble rates of reduction of the natural particles in the lake (Tipping et al., 1981). Physical contact also plays a part in the reduction process although the enclosure of the $\mathrm{Fe}$ (III) in a dialysis bag did not, on this occasion, reduce activity to the degree observed by Munch \& Ottow (1982). The extracellular reduction of $\mathrm{Fe}(\mathrm{III})$ has been reported elsewhere as an alternative mechanism to the use of siderophores for the mobilization of iron (Anderson \& Morel, 1980).

The experiments with cell-free extracts and whole cells of the fermentative bacterium, tentatively assigned to the genus Vibrio, did not provide conclusive proof of energy conservation associated with $\mathrm{Fe}$ (III) reduction. No increase in molar growth yield was observed in the presence of $\mathrm{Fe}$ (III) and it was assumed that the iron was used as a hydrogen sink, to allow the regeneration of NAD via electron transport not linked to ATP production. A facultatively anaerobic and chemolithotrophic bacterium was also isolated from the profundal sediment. A greater yield of the organism was obtained in the presence of Fe(III). This is believed to be the first demonstration of energy conservation associated with $\mathrm{H}_{2}$ transport to $\mathrm{Fe}$ (III) which has been measured in terms of biomass rather than increased viable counts (Balashova \& Zavarzin, 1979). The importance of such processes in the reduction of Fe(III) in the lake hypolimnion is not yet known. Although little difficulty has been experienced in the isolation of bacteria which use $\mathrm{Fe}$ (III) as a hydrogen sink, lithotrophs and organotrophs which may use the process to conserve energy deserve further attention.

We thank L. Hetherington for her technical assistance, E. W. Tipping for valuable discussions on the nature of iron oxides, T. Furnass who prepared the figures and Mrs J. Hawksford and Miss E. M. Evans who typed the script. This research was financed by the Natural Environment Research Council.

\section{REFERENCES}

Anderson, M. A. \& Morel, F. M. (1980). Uptake of $\mathrm{Fe}(\mathrm{II})$ by a diatom in oxic culture medium. Marine Biology Letters 1, 263-268.

Balashova, V. V. \& Zavarzin, G. A. (1979). Anaerobic reduction of ferric iron by hydrogen bacteria. Microbiology (English translation of Mikrobiologiya) 48, 733-778.

BRADFORD, M. M. (1976). A rapid and sensitive method for the quantitation of microgram quantities of protein using the principle of protein-dye binding. Analytical Biochemistry 72, 248-254.

DAVISON, W. (1981). Supply of iron and manganese to an anoxic lake basin. Nature, London 290, 241-243.

Davison, W., Heaney, S. I., Talling, J. F. \& RigG, E. (1981). Seasonal transformation and movements of iron in a productive English lake with deep-water anoxia. Schweizerische Zeitschrift für Hydrologie 42 , 196-224.

HARRIS, R. F. \& Sommers, L. E. (1968). Plate-dilution frequency technique for assay of microbial ecology. Applied Microbiology 16, 330-334.

Hughes, D. E., WimpenNy, J. W. T. \& Lloyd, D. (1971). The disintegration of micro-organisms. Methods in Microbiology 5B, 1-54.

JONEs, J. G. (1976). The microbiology and decomposition of seston in open water and experimental enclosures in a productive lake. Journal of Ecology 64, 241-278.
JONES, J. G. (1981). The population ecology of iron bacteria (genus Ochrobium) in a stratified eutrophic lake. Journal of General Microbiology 125, 85-93.

JONES, J. G. (1983). A note on the isolation and enumeration of bacteria which deposit and reduce ferric iron. Journal of Applied Bacteriology (in the Press).

JoNES, J. G. \& SnMON, B. M. (1975). An investigation of errors in direct counts of aquatic bacteria by epifluorescence microscopy, with reference to a new method for dyeing membrane filters. Journal of Applied Bacteriology 39, 317-329.

JONES, J. G. \& SIMON, B. M. (1977). Increased sensitivity in the measurement of ATP in freshwater samples with a comment on the adverse effect of membrane filtration. Freshwater Biology 7, 253-260.

JoNes, J. G., Simon, B. M. \& GARDENER, S. (1982) Factors affecting methanogenesis and associated anaerobic processes in the sediments of a stratified eutrophic lake. Journal of General Microbiology 128, $1-11$.

LAsCElles, J. \& BuRke, K. A. (1978). Reduction of ferric iron by L-lactate and DL-glycerol-3-phosphate in membrane preparations from Staphylococcus aureus and interactions with the nitrate reductase system. Journal of Bacteriology 134, 585-589.

LATHAM, M. J. \& Wolin, M. J. (1978). Use of a serum bottle technique to study interactions between strict 
anerobes in mixed culture. In Techniques for the Study of Mixed Populations (Society for Applied Bacteriology Technical Series No. 11), pp. 113-124. Edited by D. W. Lovelock \& R. Davies. London: Academic Press.

Mackereth, F. J. H., Heron, J. \& Talling, J. F. (1978). Some revised methods of water analysis for limnologists. Freshwater Biological Association Scientific Publication No. 36.

MoRTIMER, C. H. (1941). The exchange of dissolved substances between mud and water in lakes. I and II. Journal of Ecology 29, 280-329.

MORTIMER, C. H. (1942). The exchange of dissolved substances between mud and water in lakes. III and IV. Journal of Ecology 30, 147-201.

Munch, J. C. \& OtTow, J. C. G. (1977). Model experiments on the mechanism of bacterial ironreduction in water-logged soils. Zeitschrift für Pflanzenernährung, Düngung und Bodenkunde 140, 549562.

Munch, J. C. \& OTtow, J. C. G. (1982). Effect of cell contact and iron(III) Oxide form on bacterial iron reduction. Zeitschrift für Pflanzenernährung, Düngung und Bodenkunde 145, 66-77.

Obuekwe, C. O., Westlake, D. W. S. \& CoOK, F. D. (1981). Effect of nitrate on reduction of ferric iron by a bacterium isolated from crude oil. Canadian Journal of Microbiology 27, 692-697.

Oттош, J. C. G. (1970). Selection, characterization and iron-reducing capacity of nitrate reductaseless (nit $\left.{ }^{-}\right)$mutants from iron-reducing bacteria. Zeitschrift für allgemeine Mikrobiologie 10, 55-62.

OTTOW, J. C. G. \& Glathe, H. (1971). Isolation and identification of iron-reducing bacteria from gley soils. Soil Biology and Biochemistry 3, 43-55.

OtTow, J. C. G. \& MuNCH, J. C. (1978). Mechanisms of reductive transformations in the anaerobic microenvironment of hydromorphic soils. In Environmental Biogeochemistry and Geomicrobiology 2, pp. 483-491. Edited by W. E. Krumbein. Ann Arbor, Michigan: Ann Arbor Science Publishers.

STANDING COMmITTEE of ANAL YSTS (1977). Iron in raw and potable waters by spectrophotometry (using 2,4,6-tripyridyl-1,3,5-triazine). In Methods for the Examination of Waters and Associated Materials, pp. 1-12. London: Her Majesty's Stationery Office.

TAKAI, Y. \& KaMURA, T. (1966). The mechanism of reduction in waterlogged paddy soil. Folia microbiologica 11, 304-313.

Thauer, R. K., Jungermann, K. \& Decker, K. (1977). Energy conservation in chemotrophic anaerobic bacteria. Bacteriological Reviews 41, 100-180.

TIPPING, E., WoOF, C. \& COOKE, D. (1981). Iron oxide from a seasonally anoxic lake. Geochimica et cosmochimica acta 45, 1411-1419.

VERDOUW, H. \& DEKKERS, E. M. J. (1980). Iron and manganese in Lake Vechten (The Netherlands); dynamics and role in the cycle of reducing power. Archiv für Hydrobiologie 89, 509-532. 